\title{
Septal Perforator Artery
}

National Cancer Institute

\section{Source}

National Cancer Institute. Septal Perforator Artery. NCI Thesaurus. Code C102348.

The arteries arising from the right posterior descending artery that supply the interventricular septum. 